\section{Sissi, a Imperatriz: entrevista com Sisleide Lima do Amor}

Silvana Vilodre Goellner

Universidade Federal do Rio Grande do Sul (UFRGS), Porto Alegre/Brasil Doutora em Educação, UNICAMP vilodre@gmail.com

RESumo: Entrevista com Sissi realizada na cidade de Concord, Estados Unidos, no dia 27 de novembro de 2015, abordando aspectos de sua trajetória esportiva, jogadora fundamental da primeira geração de futebolistas depois de revogado o Decreto-Lei 3.199 que proibia a participação de mulheres em várias modalidades esportivas. Detentora da Camisa 10 é reconhecida como a Imperatriz do futebol brasileiro, sendo a única brasileira a integrar o FIFA Legends.

Palavras-chave: Futebol; Mulheres; Gênero; Memória; História Oral.

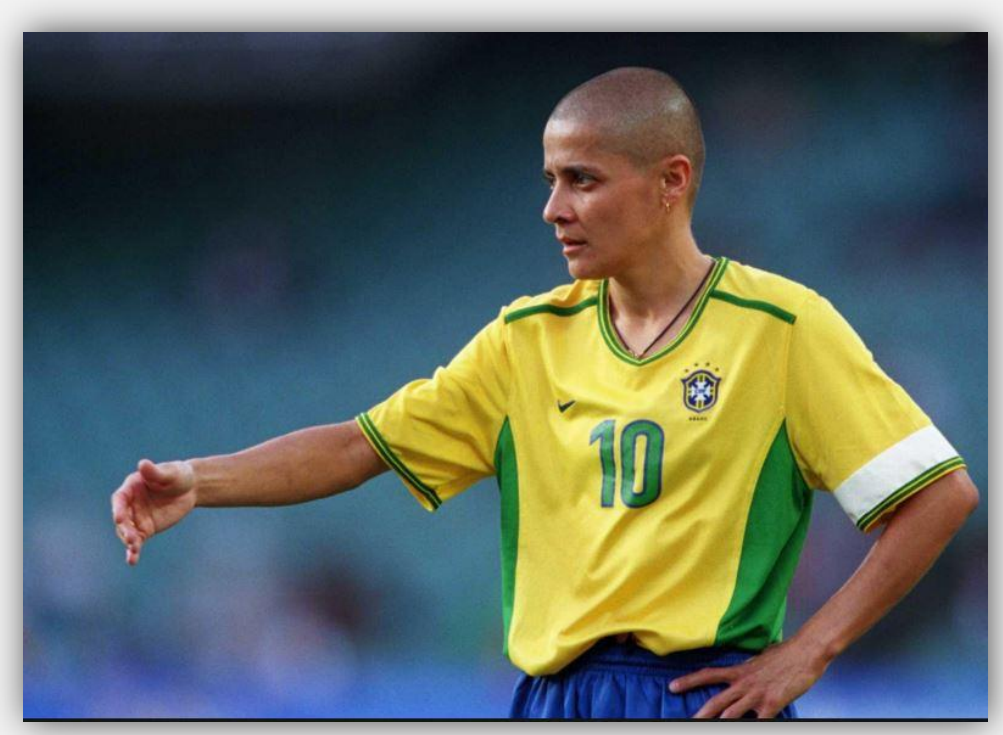

Baiana, nascida no dia 02 de junho de 1967, Sisleide Lima do Amor é um ícone do esporte mundial. Iniciou no futebol aos sete anos participando de algumas peladas na companhia do irmão e do pai, que também era jogador de futebol. Em 1979, essa história começou a mudar: diferente de Esplanada onde jogava com meninos, Sissi encontra outras meninas aficionadas pelo esporte e a organização de uma equipe na escola na qual estudava, em Campo Formoso, proporcionou a participação em jogos na região e o reconhecimento de seu talento e habilidade. 
Em um campeonato disputado na cidade de Senhor do Bom Fim, chamou a atenção da proprietária do Grêmio Futebol Clube, que a convidou para integrar a equipe. Como um efeito cascata, por onde passava, surgiam novos convites.

Mudou-se para Feira de Santana, de lá para Salvador e, posteriormente para o Rio de Janeiro, para integrar a equipe do Esporte Clube Radar, time referência da década de 1980 e a base da primeira seleção nacional convocada em 1988 para disputar um torneio na China organizado pela FIFA, uma espécie de competição preparatória para o I Campeonato Mundial de Futebol Feminino realizado em 1991 no mesmo país. Sissi não participou do Mundial em função de uma lesão. Vestiu a amarelinha no Mundial de 1995, realizado na Suécia, e no de 1999, que aconteceu nos Estados Unidos, no qual o Brasil conquistou a terceira colocação. Sissi, ao lado da chinesa Sun Wen, foi artilheira da competição com sete gols marcados. Eleita pela FIFA a segunda melhor jogadora do mundo, em janeiro de 2000, recebeu a Bola de Prata da Adidas. Sua atuação no futebol nacional inclui passagem por equipes como o
Bahia, Saad, São Paulo, Palmeiras, Corinthians e Vasco. Sissi também atuou no futebol de salão, um modo de permanecer atuando diante da escassez de campeonatos e equipes.

Na seleção brasileira fez mais história: em 1996, participou dos Jogos Olímpicos de Atlanta, quando o futebol feminino passou a integrar o programa olímpico, e, em 2000, foi aos Jogos Olímpicos de Sidney. Desde 2001, atua nos Estados Unidos. Inicialmente, como jogadora do San Jose CyberRay e do Califotrnia Storm e como treinadora, a partir de 2004. Em 2016, tornou-se a única brasileira FIFA Legend, uma honraria. A trajetória de Sissi tem reconhecimento mundial. Seu posicionamento dentro e fora de campo fez e faz dela o que é.

Preocupada com a situação do futebol de mulheres no Brasil, há muito tempo vem entoando sua voz em defesa da modalidade. Em 2017, foi uma das signatárias da Carta Aberta encaminhada à Confederação Brasileira de Futebol conclamando a instituição a fazer reformas em prol da igualdade de gênero neste esporte. 
Silvana Vilodre Goellner: Sissi, inicialmente gostaria de agradecer tua disponibilidade em conceder essa entrevista. Certamente ela será um importante registro para a história do futebol de mulheres no Brasil. Para dar início a nossa conversa, eu te pediria que falasses sobre sua infância e quando iniciaste a jogar futebol.

Sissi: BOM, EU COMECEI COM SETE ANOS DE IDADE BASICAMENTE. VI MEU PAI E MEU IRMÃO JOGANDO NO QUINTAL, COMO ELES FALAVAM, BATENDO UMA PELADA NO FINAL DA TARDE. Foi assim que eu me interessei, mas o que eles faziam? Me colocavam de bobinho! Eles achavam que naquele tempo futebol não era para meninas, então eles falavam: "Você pode participar, mas você vai ser a bobinha". Então eu ficava no meio [risos].

Silvana: Você tinha um só irmão?

Sissi: É, meu irmão mais velho. Ele tinha talento, meu pai também foi jogador. Era zagueiro e, geralmente, nos finais de semana eu ia aos jogos, acompanhava, mas era aquele bando de homem de idade jogando nos finais de semana. Assim, minha paixão começou vendo os dois jogando e naquele tempo o sonho do meu pai era que meu irmão se tornasse jogador profissional. Ele chegou a fazer testes no Bahia ${ }^{1}$ e no Vitória, ${ }^{2}$ mas não era o que ele queria. Ele achava que meu irmão queria ganhar maioridade, sair, ganhar dinheiro, trabalhar, ele não pensava em ser jogador profissional. Naquele tempo, na minha cidade não tinha meninas jogando, eu era a única menina. Minha cidade é muito pequena, ${ }^{3}$ então, às vezes, quando ele escondia a bola, eu ia lá arrancava... comecei a arrancar a cabeça das minhas bonecas [risos].

Silvana: Que ótimo. Você fazia bola com as cabeças das tuas bonecas?

Sissi: Sim. Era bola de meia, tampinha de garrafa, tudo que dava para chutar. Na época, principalmente, no fim de ano, quando eles perguntavam o que eu queria de presente de natal eu sempre escolhia aquelas bonecas que eu podia arrancar a cabeça [risos]. Minha mãe falava: "Meu Deus, essa mulher deve estar com algum problema, não é possível!" [risos]. As

\footnotetext{
${ }^{1}$ Esporte Clube Bahia.

2 Esporte Clube Vitória.

${ }^{3}$ Referência à cidade de Esplanada, na Bahia.
} 
minhas irmãs, a minha irmã mais velha escondia as bonecas, aquelas de cabeça macia... Até hoje minha mãe ainda tem uma caixa com as cabeças [...]. Eu conto isso e o povo não aguenta, mas era uma loucura. Eu ficava no quintal às vezes, era tarde e eu lá chutando. Chegava com os dedos todos arrebentados.

Silvana: Isso era o quê? Década de 1980 ?

Sissi: É exatamente. Aí, MINHA AVó FICAVA DURA E ACHAVA QUE MINHA MÃE TINHA QUE PARAR COM ISSO, QUE FUTEBOL ERA COISA DE HOMEM. Tudo mudou quando meu pai foi transferido de Esplanada para a cidade de Campo Formoso, ele trabalha em construção de estrada. Eu estava com onze anos de idade e a gente teve que se transferir. Largamos tudo, minha avó, minha família toda a gente teve que sair de lá.

Já em Campo Formoso, na primeira escola eu conheci duas meninas que também já praticavam. Sabe que futebol naquela época era proibido, né? Eu já ouvia falar do Radar, ${ }^{4}$ eu acompanhei um pouco da história dele e sabia que tinha um time organizado no Rio de Janeiro e tudo mais... Mas a minha par-

\footnotetext{
${ }^{4}$ Esporte Clube Radar.
}

ticipação jogando em time mesmo foi na minha escola. A gente fez um time e jogava contra as equipes das escolas, mas era só de brincadeira, tinham os jogos regionais, a gente representava a Escola Polivalente e jogava contra as escolas da região. Foi aí que a gente resolveu fazer um time só de mulheres para jogar com algumas equipes que tinham naquela região de Campo Formoso, de Senhor do Bom Fim. Assim eu conheci a Miriam Vanderley que era dona do Grêmio Futebol Clube da cidade de Senhor do Bom Fim e a gente fez um amistoso. 0 time lá da cidade de Senhor do Bom Fim, da escola, contra o Grêmio. Ela me convidou para jogar no Grêmio Futebol Clube, foi o primeiro time organizado mesmo, e jogos regionais naquela época lá eram jogos... o bicho pegava.

Silvana: Você participava de muitas competições?

Sissi: Sim, aí eu saí e fui jogar pela equipe dela do Grêmio. Foi meu primeiro time só de mulheres. Nos jogos regionais a gente enfrentou o Flamengo de Feira de Santana, ${ }^{5}$ que foi fazer um jogo na cidade de Senhor do Bom Fim. Foi quando eu co-

\footnotetext{
${ }^{5}$ Flamengo de Feira Futebol Clube.
} 
nheci o Michelin, ${ }^{6}$ que era dono do Flamengo, do masculino e do feminino. Quando a gente fez o preliminar, o Michelin gostou, conversou com a Miriam e falou a meu respeito. ElE NOS CONVIDOU PARA IRMOS PARA FEIRA DE SANTANa E EU TINHA 14 ANOS. ElE FOI À MINHA CASA, FALOU COM MEUS PAIS. MiNHA MÃE DISSE: "De Jeito nenhum você vai Pra Feira de Santana com 14 ANOS!”. EU FALEI: “EU QUERO IR, EU QUERO IR!” Lembro que eu arrumei um pano lá com as minhas roupas [risos] e minha irmã falava: "Você vai pra onde?" Eu falei: "Ah... eu tô me mudando!". Minha irmã: "Você é doida, você não vai pra Feira de Santana!". EU PEDI, IMPLOREI PARA OS MEUS PAIS, ATÉ QUE MINHA MÃE FALOU: “Tudo BEM!". Mas eu tive que prometer que ia acabar os estudos nesse período que eu fosse pra Feira de Santana. Ela chegou até ir para Feira pra olhar onde a gente ia ficar e tudo mais, mas eu tive que prometer que eu ia me dedicar também aos meus estudos. Aí eu me mudei de Campo Formoso juntamente com a Miriam para Feira de Santana para jogar no Flamengo. Morei em uma casa com dez meninas, foi quan-

\footnotetext{
${ }^{6}$ Edmilson Amorim
}

do eu conheci a Solange, ${ }^{7}$ a Soró, e eu era a mais nova daquele grupo, então, lá a gente era uma família. Não tinha supervisão nem nada, às vezes o Michelin vinha no final da noite, por exemplo, por volta das $10 \mathrm{~h}$ e a gente tinha que estar com a televisão desligada, ele vinha e colocava a mão na televisão [risos].

Silvana: Para ver se estava quente...

Sissi: Televisão daquele tempo! Ele vinha toda noite, a gente via o carro dele de longe, a gente desligava a televisão [risos], ele vinha já colocava a mão na televisão e já dava para saber que a gente estava acordada. Tinha horário pra ir pra cama, horário de acordar, horário dos treinos, horário de ir pra escola... A gente ia para a escola juntas, voltava e tinham os treinos. A competição na época era muito forte no campeonato baiano. Tinha o Bahia, tinha uma equipe lá, não lembro o nome... O campeonato baiano foi o primeiro campeonato organizado que eu participei jogando pelo Flamengo.

Silvana: Pelo Flamengo de Feira de Santana?

\footnotetext{
${ }^{7}$ Solange Bastos.
} 
Sissi: Eu fiquei no Flamengo uns três anos, até que recebi uma proposta para ir jogar no Bahia. Aí eu saí do Flamengo e fui jogar no Esporte Clube Bahia. Me mudei de Feira de Santana para Salvador, onde eu conheci a Nalvinha. ${ }^{8}$ A Miriam também foi, chegou até a jogar um tempo no Bahia e foi naquela época que o Radar já tava...

Silvana: Se estruturando, que era o grande time do momento.

Sissi: E ao mesmo tempo eu jogava futebol de salão, jogando pelo Bahia e disputava campeonatos de futebol de salão e também jogava futebol de campo e montaram a primeira seleção, que foi a base do Radar. 0 Radar chegou até ir pra Itália antes de participar do primeiro mundial que não foi reconhecido pela FIFA, então o Radar já tinha ido jogar representando a seleção brasileira na Itália.

Silvana: Isso no Mundialito de Futebol Feminino que aconteceu na Itália em 1986? Nesse jogo tu não foste?

Sissi: Eu não cheguei a ir. Na hora que elas voltaram, foi aí que eu fui chamada pra ir jogar pela Seleção Brasileira, que foi a

\footnotetext{
${ }^{8}$ Lunalva Torres de Almeida.
}

primeira. Algumas meninas jogavam pelo Bahia, a gente foi para o Rio de Janeiro e foi convocada a primeira seleção brasileira.

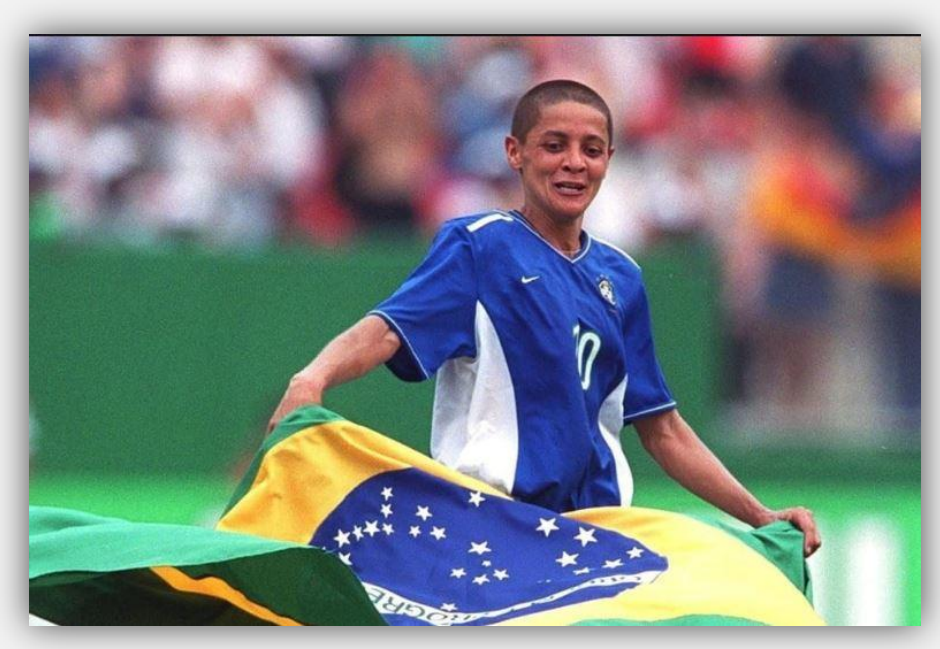

Silvana: Depois que voltaram da Itália, mas isso foi em $1988 ?$

Sissi: É, a GENTE FOI PRA CHINA EM 1988. FoI A PRIMEIRA SELEÇÃo E A GENTE PARTICIPOU DE CAMPEONATO ORGANIZADO PELA FIFA QUE FoI NA CHINA. Era a base do Radar com Michael Jackson, ${ }^{9}$ Roseli, ${ }^{10}$ Fanta. ${ }^{11}$ Seleção fora de série! Aquele grupo era um grupo

\footnotetext{
Mariléia dos Santos.

${ }^{10}$ Roseli de Belo.

${ }^{11}$ Rosilane Camargo Motta.
} 
especial: a Suzi, ${ }^{12}$ a Flordelis, ${ }^{13}$ a Nalvinha, a Suzana, ${ }^{14}$ a Marisa, ${ }^{15}$ a Russa, ${ }^{16}$ a Elane. ${ }^{17}$ Então a gente foi pra China, foi o primeiro Campeonato Mundial ${ }^{18}$ que para a gente era um sonho, mas ainda não tinha noção do que ia acontecer depois. A gente era muito nova, mas aquele sonho de criança que eu já tinha!

Silvana: Você tinha o quê, 20 anos, por aí? Nesse momento a base da seleção era o Radar, jogadoras da Bahia e algumas jogadoras do São Paulo?

Sissi: Exatamente. Nossa Senhora, pra mim foi uma coisa inesquecível! Eu acho que ainda tenho a roupa que a gente usou pra ir para o Mundialito, na época do Eurico Lira, que até já faleceu, mas a gente foi sem saber, quando a gente vai sem...

Silvana: Sem ter dimensão do que representava a competição?

\footnotetext{
${ }^{12}$ Suzy Bittencourt de Oliveira.

13 Flordelis Santos Oliveira.

${ }^{14}$ Susana Cavalheiro.

${ }^{15}$ Marisa Pires Nogueira.

${ }^{16}$ Márcia Matos Calaça.

${ }^{17}$ Elane dos Santos Rego.

${ }^{18}$ Mundialito de Futebol Feminino de 1988, realizado na China.
}

Sissi: Sim, do que era, mas quando a gente jogou na China... Nossa tudo aquilo pra mim foi um aprendizado, mas ao mesmo tempo era um conto de fadas, vamos falar assim, era uma fantasia pra mim. Aí comecei a relembrar tudo que eu tive que passar e do que a gente teve que... Cada passo pra chegar até aquele ponto e aí quando a gente retornou do Mundialito a gente ficou em terceiro lugar.

Silvana: Vocês já retornaram com a medalha de bronze?

Sissi: É. Basicamente foi um trabalho... Tudo bem que o Radar foi quem deu a cara pra aquela seleção, então, já tinha mais ou menos uma estrutura.

Silvana: E vocês tiveram uma preparação para o campeonato, passaram um tempo no Rio de Janeiro?

Sissi: É, no Rio de Janeiro e foi uma preparação, vamos dizer que foi até normal. A gente querendo ou não teve um apoio da CBF na época e quando a gente retornou do mundial era tipo assim: "Mas e agora o que vai acontecer?". Algumas meninas já tinham clubes, já tinham trabalho, mas, no meu caso: "E agora vou voltar pra Bahia e continuar jogando pelo Bahia?". 
Aí eu recebi o convite: "Vem jogar em São Paulo, jogar pelo Corinthians". ${ }^{19}$ Aí joguei com a Márcia Honório, ${ }^{20}$ mas o Corinthians era mais pra jogar futebol de salão. Daí eu saí de Salvador e fui para São Paulo morar em uma república, a gente morava lá, como era o nome... esqueci o nome da cidade. Eu LEMBRO QUE A GENTE TINHA QUE TODO DIA PEGAR O ÔNIBUS E IR PARA 0 CENTRO TREINAR No CírCUlo MilitaR, PORQUE O TREINAdor ERA Militar. A gente CHEgava À NOITE, Às VEZES, CANSADA PRA CARAMBA DEPOIS DO TREINO, PEGAVA O ÔNIBUS E ERA UMA VIAGEM PRA CARAMBA, PORQUE A GENTE MORAVA NO INTERIOR. Foi acontecendo sabe, a gente já querendo ou não já ganhava alguma coisa, mas não era um salário pra você falar: "Ah... dá pra sobreviver". Eu cheguei até a trabalhar em uma oficina que vendia peças pra carros. Mas eu falei: “Que é isso?" Naquele tempo, sabe, ao mesmo tempo para tentar sobreviver, porque o salário não era muito, então eu comecei a jogar um campeonato de futebol de salão; um campeonato muito forte naquela épo-

\footnotetext{
${ }^{19}$ Sport Clube Corinthians Paulista.

${ }^{20}$ Márcia Honório da Silva.
}

ca, tinha o Corinthians aí começou a Marvel...21 Acho que o salão me ajudou bastante, eu sempre falo que o futebol de salão te obriga a pensar muito rápido, decidir muito rápido, ter visão de jogo, mas, o meu negócio era mais no campo. Então depois do Corinthians tive a chance de jogar pela Bordon, aí na Bordon foi a Marvel, depois da Marvel e a Associação Sabesp de Santos.

Silvana: Você jogou na Sabesp?

Sissi: A Sabesp foi realmente a equipe que me ajudou e muito em termos financeiros, em termos de estrutura. A Bordon também foi uma equipe que, querendo ou não, pagou até muito bem e tinha uma estrutura fenomenal.

Silvana: Isso era futebol de salão ainda?

Sissi: Sim. Então eu comecei a me dedicar mais ao salão do que ao campo, porque naquela época o salão era mais estruturado, tinha uma estrutura melhor do que o campo, então, aquela equipe da Bordon, da Marvel pagaram e pagaram muito bem. Foi aí que eu comecei a ganhar e tive que guardar

\footnotetext{
${ }^{21}$ Sociedade Esportiva e Recreativa Marvel.
} 
porque o meu sonho era continuar, sei lá comprar uma casa, ajudar meus pais, minha família, porque por causa deles que eu cheguei aonde cheguei. Eles também tiveram que fazer bastante sacrifício porque não foi fácil, então, quando eu vi que o futebol de salão naquela época estava tendo mais visão, a aceitação era muito maior.

Silvana: Você foi para o futebol de salão...

Sissi: É, e fiquei, joguei, depois veio a Euroexsporte. Muita gente conseguiu ganhar bastante e muito bem na época da Euroexporte, que tinha uma base na Bahia e uma base no São Paulo, que a Roseli e algumas meninas vieram do Rio jogar. Jogaram também pela Euro de São Paulo e se você for olhar bem, naquela época de futebol de salão, a competição era bastante forte, se você der uma pesquisada. Até as meninas do Rio saíram do Rio e ficaram morando em São Paulo por causa do futebol de salão. Quando a gente voltou novamente para jogar o futebol de campo foi já perto do Mundial de
1991,22 que eu fui convocada, mas acabei não participando porque me machuquei.

Silvana: Então, na Copa do Mundo da FIFA você foi só em 1995, na Suécia?

\section{Sissi: É, Aí EU TIVE QUE FICAR DE FORA DAQUELA SELEÇão DE 1991,} PORQUE ACABEI ME MACHUCANDO. O futebol de salão era mais forte que o de campo, aí mudou em 1991. Eles começaram até a valorizar mais e apostar mais no futebol de campo.

Silvana: Depois da Copa do Mundo?

Sissi: Depois do Mundial, então, foi quando o Saad ${ }^{23}$ apareceu com o futebol de campo. E já foi chegando perto do Mundial de 1995. Foi a minha segunda, vamos dizer, participação, mas minha primeira participação oficialmente, quando o Ademar foi o treinador. ${ }^{24}$ Acho que eu jogava na Sabesp e era futebol de salão, praticamente levou a grande maioria das jogadoras. Então, logo depois a gente foi pra Suécia, eu lembro que a gente teve que lutar pra caramba pra se classificar e jogar Jogos

\footnotetext{
${ }^{22}$ Copa do Mundo de Futebol Feminino de 1991, realizada na China.

${ }^{23}$ Saad Esporte Clube.

${ }^{24}$ Ademar Fonseca.
} 
Olímpicos de Atlanta, Realizados em 1996. No PRimeiro jogo contra a Alemanha a gente tomou uma sacolada. Meu Deus, uma SaColada da Alemanha. FoI QUando, SABE Quando você COMEÇA A RECONHECER A SUPERIORIDADE DOS TIMES, DAS SELEÇÕES Europeias? Eu falei: “Meu Deus!". Acho que ficou guardado porque dá pra notar a diferença em termos de, não de técnica, mas de físico. Quando a gente viu, acho que foi a primeira vez que eu vi a Prinz ${ }^{25}$ jogando, uma jogadora excepcional jogando pela seleção alemã. Eu lembro que ela passava pela zaga, parecia um trator. Mas é o que eu falo, naquela época o futebol feminino em termos de grupo era mais forte, as jogadoras eram, não era uma jogadora que se destacava, era um grupo todo. Se você pegar a Suécia... A Suécia não era fácil de ganhar, de jogar contra, a Alemanha também não era fácil, a Noruega tinha uma seleção que, meu Deus do céu... 0 Japão começou também, os Estados Unidos já dava pra notar e a gente estava tipo engatinhando. E a gente acabou se classificando para as Olimpíadas, e nesse período eu cheguei a ir para Itália jogar

\footnotetext{
${ }^{25}$ Birgit Prinz.
}

no Verona. ${ }^{26}$ Eu cheguei a ir pra lá, fiquei quase um mês, fui jogar para o time da Duda. ${ }^{27}$ Eu tive que voltar, tive que me apresentar pra jogar o Sul-Americano e eles não aceitaram; eles falaram que se eu voltasse pra jogar pela seleção era melhor ficar no Brasil. Então, eu tive que desistir, não cheguei a ficar na Itália. Fiquei 28 dias e tive que voltar para o Brasil e aí jogamos nas Olimpíadas 1996 que foi aqui nos Estados Unidos.

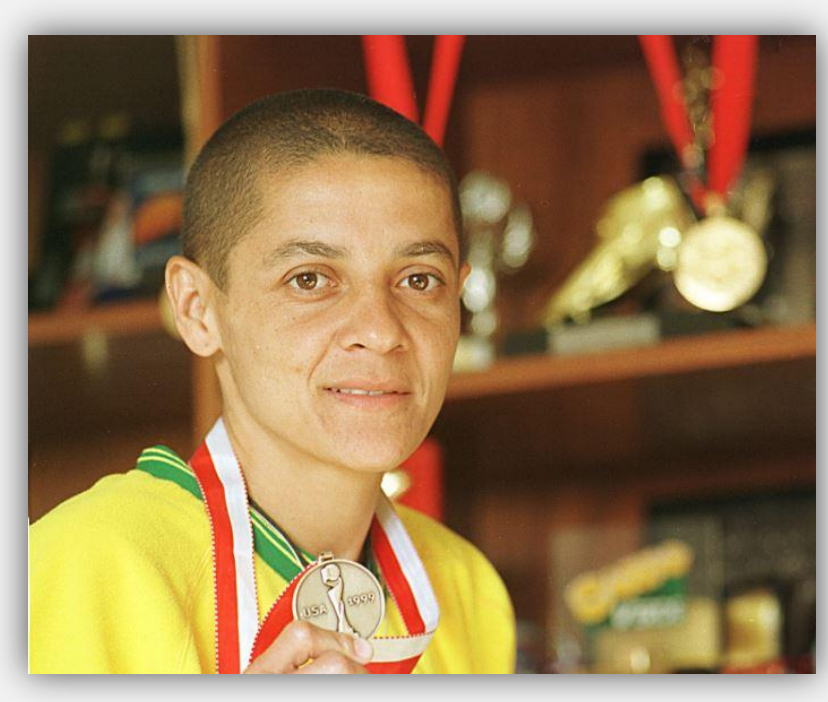

\footnotetext{
${ }^{26}$ Hellas Verona Football Club.

${ }^{27}$ Eduarda Marranghelo Luizelli.
} 
Silvana: Daí você continuou jogando no Brasil? Quando você veio para os Estados Unidos? Você veio logo depois pra cá?

Sissi: No Brasil joguei pelo Saad, que depois se tornou o São Paulo, ${ }^{28}$ foi o São Paulo que ganhou tudo no Brasil, foi aquela equipe que todo mundo falou e fala até hoje. Naquela época, quem disputou aquele campeonato, não foi um campeonato assim: "A gente vai fazer hoje e terminar". Não. Joguei uns dois anos mais ou menos pelo campeonato, e eu joguei pelo São Paulo, depois pelo Palmeiras, ${ }^{29}$ depois fui para o Rio de Janeiro jogar pelo Vasco. ${ }^{30}$ Foi na época que o Eurico Lira resolveu ter todos aqueles atletas, foi disputar as Olimpíadas e queria que todo mundo, os principais atletas fizessem parte do Vasco. Joguei o Mundial, ${ }^{31}$ DEPois as Olimpíadas de $1996{ }^{32}$ E o Mundial EM 1999,33 E, LOGo EM SEGUIDA, EU VIM PARA OS ESTADOS UnIDOS.

\footnotetext{
${ }^{28}$ São Paulo Futebol Clube.

29 Sociedade Esportiva Palmeiras.

${ }^{30}$ Clube de Regatas Vasco da Gama.

${ }^{31}$ Copa do Mundo de Futebol Feminino de 1995, realizada na Suécia.

32 Jogos Olímpicos de Atlanta realizados em 1996.

${ }^{33}$ Copa do Mundo de Futebol Feminino de 1999, realizada nos Estados Unidos.
}

Foi quando eles fizeram o All Star pra jogar contra a seleção americana e aí jogamos em várias cidades aqui dos Estados Unidos, mais in door quando eles fizeram o Victory Tour que eles falavam. Então quando elas ganharam o Mundial, em 1999, eles fizeram um All Star pra jogar, eu vim, participei da equipe jogando contra a seleção dos Estados Unidos e logo em seguida QUANDO EU RETORNEI AO BRASIL A GENTE FOI E DISPUTOU as Olimpíadas EM 2000, na AuSTrália, EM Sidney, 34 E FOI Minha ÚLTIMA PARTICIPAÇÃO PELA SELEÇÃO.

Aí voltei para o Brasil e foi quando eles falaram que ia ter a liga profissional WUSA (Women's United Soccer Association). Eles me convidaram e eu vim jogar na equipe de San Jose CyberRays com a Kátia. ${ }^{35}$ A Pretinha ${ }^{36}$ e a Roseli37 foram para Washington e eu e a Kátia viemos aqui pra San Jose.

Silvana: E você ficou definitivo? Desde 2001, você está aqui?

\footnotetext{
34 Jogos Olímpicos de Sydney, realizados em 2000.

${ }^{35}$ Kátia Cilene Teixeira da Silva.

${ }^{36}$ Delma Gonçalves.

${ }^{37}$ Roseli de Belo.
} 


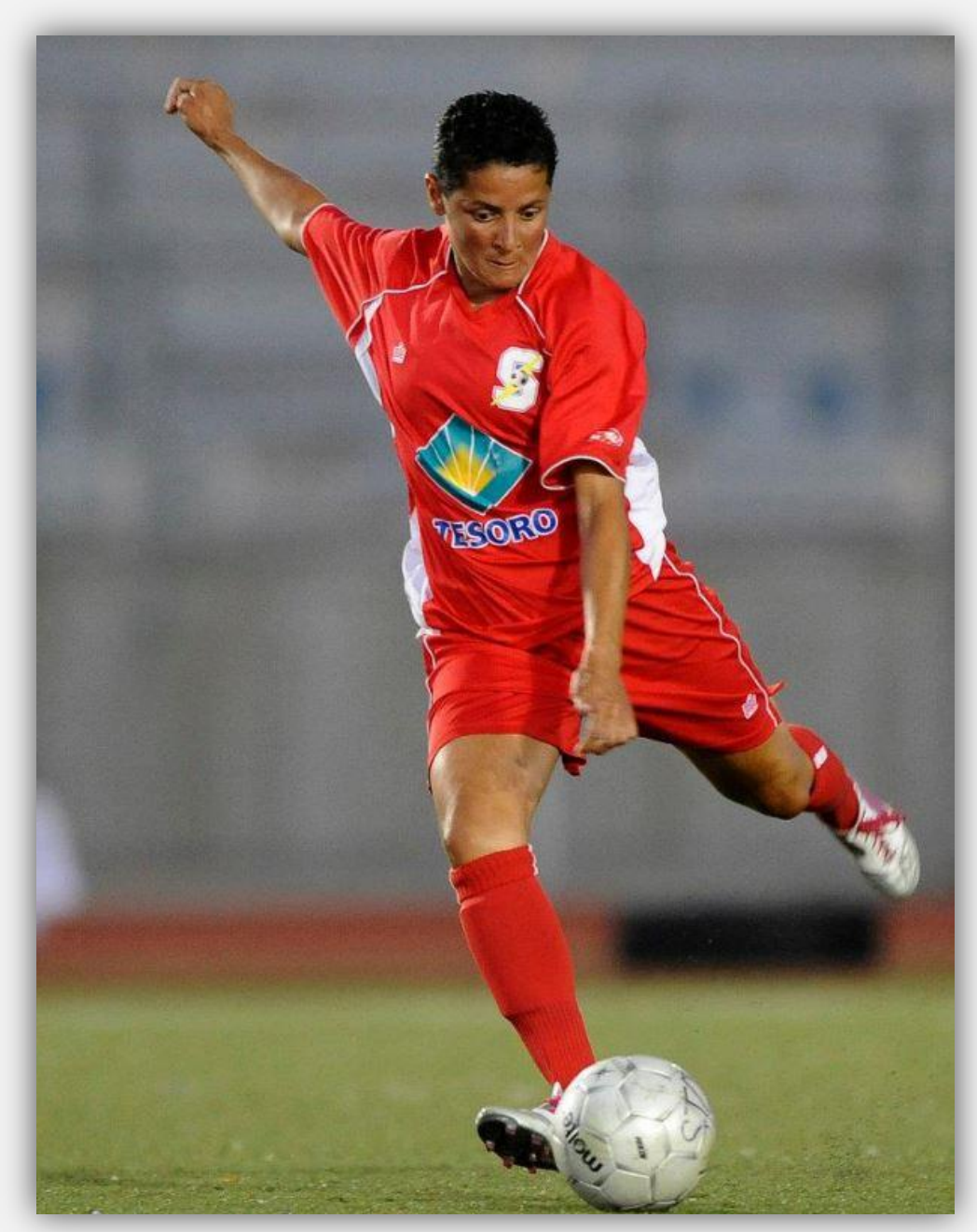

Sissi: Fiquei, mas voltei depois para o Brasil e joguei alguns jogos pelo Saad. O Romeu me convidou pra jogar, ${ }^{38}$ não lembro se foi o Campeonato Paulista, a gente ia jogar a semifinal e a final, mesmo jogando aqui nos Estados Unidos.

Silvana: E você jogou no San Jose?

Sissi: Joguei uns três anos pelo San Jose CyberRays, ganhamos o primeiro campeonato em 2001 e, em 2003, a liga acabou por falta de patrocínio. Eu voltei e quando eu estava no Brasil o Jerry Zanelli que é o commission of the WPSL que tem um time, o California Storm me convidou pra jogar na liga que é semiprofissional. Eu voltei e resolvi ficar por aqui.

Silvana: E quando você começou a trabalhar aqui como treinadora?

Sissi: Em 2004, QUANDo EU ESTAVA Jogando PElo California STORM, o DVSC Diablo Valley Soccer Club ME CONVIDOU PaRA SER ASSISTENTE DO SUB-16. FOI MINHA PRIMEIRA PARTICIPAÇÃo COMO TREINADORA. Não tinha conhecimento nenhum, meu inglês era péssimo, mas eles souberam que eu estava morando

${ }^{38}$ Romeu Carvalho de Castro. 
em Walnut Creek e estava em San Jose. Eu resolvi vir para Walnut Creek por causa do trabalho, eles me chamaram para ser assistente do sub-16 e nesse período o Las Positas Juniors College também estava precisando de uma assistente do treinador. Eles entraram em contato com o Jerry e perguntaram se eu estava interessada em trabalhar no Juniors College e foi assim que eu comecei.

Silvana: E permanece até hoje?

Sissi: Até hoje, mas quando eu fui para o Las Positas... Sabe quando você, até aquele ponto eu não tinha noção da diferença entre junior college e university. Eu achava que o nível era o mesmo [risos]. Mas quando notei a diferença eu falei: "Meu Deus, a diferença é enorme!" Mas, até aí não tinha noção ainda: "Não sei se é isso que eu quero fazer, não sei se quero ficar como treinadora!" Mas, acabei gostando de trabalhar e estou até hoje. Fiquei no Las Positas uns dez anos trabalhando. Primeiro comecei como assistente, depois eu virei treinadora e o DVSC acabou e virou o DFSC. Eu fiquei no DFSC mais ou menos no total uns oito anos, daí me transferi para o Walnut
Creek há dois anos atrás e agora eu estou no Solano College como assistente de coach.

Silvana: Ou seja, tem uma carreira consolidada aqui nos Estados Unidos como treinadora. Sissi, me fala um pouquinho mais daquela seleção de 1988. Como foi para você chegar na China, saindo do Brasil para um grande campeonato?

Sissi: Nossa Senhora! Primeiro que eu não conhecia basicaMENTE NINGUÉM DAQUELA PRIMEIRA SELEÇ̃̃o BRASILEIRA, A NÃO SER AS MENINAS QUE ERAM DA BAHIA. É O QUE EU FALEI: É DIFÍCIL ENCONTRAR PALAVRAS PARA DESCREVER PRA VOCÊ A SENSAÇÃo DE REPRESENTAR A SELEÇÃo BRASILEIRA, ir jogar, ir para o Mundial fora, viajar pela primeira vez. Eu não tinha noção do que a gente ia encontrar lá fora, mas foi uma experiência, meu Deus do céu... O fato de estar representando nosso país, vestir a camisa que era um sonho que eu tinha desde quando era criança, sei lá, mas eu acho que eu só fui ter mais ou menos uma sensação do que era mesmo representar a seleção logo depois. Mas em 1988 foi o primeiro passo e também o fato de conhecer pessoas novas, formar uma amizade. 
Silvana: Você tinha uns 20 anos por aí, era novinha.

Sissi: E conhecer pessoas novas e aquelas pessoas até o que algumas vieram a ser, até fazer parte da minha família mesmo porque cheguei a morar com algumas delas depois, anos depois. Então, sei lá foi difícil porque eu era muito nova, não tinha ainda uma noção do que era aquilo.

Silvana: Se não me engano foi a Susana Cavalheiro que falou que o uniforme que vocês usaram era o uniforme dos homens. Que vocês tinham que costurar as camisetas à noite para diminuir o tamanho porque eram enormes. [risos] $\mathrm{Tu}$ lembras disto?

Sissi: Diminuir o tamanho... Eu lembro que a gente tinha que chegar lá na Granja Comary e tinha que, na última hora, começar a costurar porque as roupas eram muito grandes. Sim e a gente teve que provar os uniformes na última hora. Meu Deus do céu, e a gente tinha que ver quem é que sabia costurar, porque não era todo mundo que sabia costurar e eu lembro que a Susana era uma que sabia costurar, eu sei que ela teve que costurar roupa de um monte de gente [risos]. Ninguém era prendada, mas foi isso realmente, ficamos até tarde da noite arrumando a roupa e não conseguia.

Silvana: Claro que a tua carreira é imensa, mas, que momentos que tu achas que foram os mais significativos, foram inesquecíveis ao relembrar tua trajetória no futebol?

Sissi: Primeiro, o fato de começar com o Grêmio Futebol Clube. Foi o primeiro time que, querendo ou não, que abriu. Se for olhar bem, a minha trajetória vindo do Grêmio e indo para o Flamengo também tem o Michelinho que foi fundamental na minha carreira: o meu primeiro treinador. A Miriam era a jogadora, era a treinadora, mas a gente não tinha treinador, treinador mesmo foi o Michelinho. Foi o cara que realmente fez muito pelo Flamengo; não só pelo Flamengo, muitas meninas depois chegaram a participar da seleção. Realmente ele foi o cara que deu uma base, foi o cara que foi o meu segundo pai, que cuidou de mim, que procurou dar uma estrutura para aquele grupo que fez parte daquele Flamengo. O Flamengo também ganhou muita coisa lá na Bahia. Então, saindo dali e indo para São Paulo com 17 anos e jogando nas equipes de 
futebol de salão, por causa da Sabesp, foi também uma equipe que me ajudou pra caramba. Tem também tanta gente que me ajudou, algumas pessoas foram muito importantes na minha vida, na minha carreira, na minha trajetória, a minha família. Representando a seleção pela primeira vez, saindo do país pela primeira vez, marcando meu primeiro gol que foi contra a Noruega de falta, coisa que eu virei especialista. Sei lá! São tantos os momentos que se for pra escolher, eu acho que para consolidar mesmo o que aconteceu comigo em 1999 realmente foi tudo. Eu passei junto com as meninas, as dificuldades, mas foi uma coisa que não é que eu me preparei pra isso acontecer, aconteceu.

Silvana: Você foi o grande nome da seleção, foi a melhor do mundo, foi artilheira também.

Sissi: Com 30 e poucos anos isso foi acontecer, mas sei lá! É porque tinha que ser, vai ver que Deus estava preparando aquele momento, e eu nunca fui uma jogadora de marcar muitos gols, sempre fui uma jogadora de marcar, dar passe para os outros... Acho que participar da primeira seleção, da pri- meira Olimpíada e no fato de tudo isso que aconteceu comigo em 1999 realmente e depois ter a chance de jogar aqui e calando a boca de muita gente que achava que não ia dar certo.

Silvana: Pensando na estruturação do futebol, o que tu dirias para as meninas que querem jogar?

\section{SisSi: O NEGócIO É NÃO DESISTIR. No NOSSO TEMPO FOI MUITO MAIS} DIFÍCIL E NÃO DESISTIMOS. A BATALHA FOI IMENSA, SEI LÁ A GENTE FOI PERSISTENTE E DEU DE CARA, SOFREMOS BASTANTE, MAS EU ACHO DIFÍCIL COMPARAR. MUITA COISA MUDOU DAQUELE PERÍODO PARA CÁ. ACHO QUE AGORA A ACEITAÇ̃̃o ESTÁ BEM MAIOR do QUE ANTES, MAS É CLARO QUE ESSA GERAÇÃO TAMBÉM DEPENDE DOS ÓRGÃOS RESPONSÁVEIS, DEPENDE DO POVO QUERER FAZER ALGUMA COISA. Enquanto elas estiverem lutando eu sempre acho que alguma coisa vai acontecer, quando... Sei lá eu também nunca achei que fosse acontecer pra mim e aconteceu. Para nós, o negócio é continuar acreditando no sonho, acreditando que algo vai mudar e que um passo já foi dado, comparado com o que era antes.

Silvana: Vocês abriram as portas. Foi uma geração que sofreu muito nesse sentido não existia nada, inclusive era proibido. 
Vocês abriram esse caminho, a geração que está hoje só está porque vocês fizeram o primeiro movimento.

Sissi: A gente fala que queria que pelo menos no Brasil tivesse um pouco do que se tem aqui, um pouco da estrutura, dos planos, tem que ter um plano. A gente sabe que talentos o Brasil tem de sobra, mas só com talento fica difícil. Eu acho que, sei lá, dá pra ver que ainda tem uma resistência com relação a isso. Talvez seja questão de cultura, não sei se é bem isso, só queria que no Brasil tivesse um pouquinho do que tem aqui. Mas eu sou uma pessoa que ainda continua otimista porque senão você não vai pra frente. Se você só ficar pensando no que pode dar errado ou no que está dando errado e procurar como que se pode resolver nem que seja, não precisa ser uma coisa, resolver tudo de uma vez, mas eu acho que o brasileiro ainda é muito acomodado com relação a isso. Tem que se ter um plano, não é querer resolver tudo de uma vez só, mas qual o primeiro passo que tem que ser feito? Se for trabalhar nas categorias de base, então vamos dar chance para as categorias de base. Fica difícil de repente querer colher resultados quando você está na seleção sub-15, sub-17, sub-
20, é muito tarde para isso, o trabalho tem que começar de baixo, senão não vai ter renovação.

O BRASILEIRo VIVE MUITO DE RESULTADOS E DE QUERER RESULTADO AGORA. SE VOCÊ OLHAR COM RELAÇÃo À SELEÇÃO JAPONESA, QUE NINGUÉM OUVIA FALAR NO JAPÃO E OLHA O JAPÃO HOJE É UMA POTÊNCIA! SEM FALAR NA SELEÇÃo FRANCESA QUE PARA MIM, COMPARADA COM OUTRAS SELEÇÕES, É UMA SELEÇÃO QUE ME ENCHE OS OLHOS. QUANDO EU OLHO, E EU VEJO AS FRANCESAS JOGANDO, SEI QUE TUDO FOI UM PLANEJAMENTO. Não foi um planejamento assim: vamos colher os resultados daqui a um ano. A gente vem batendo na tecla com relação ao Brasil desde quando jogava na seleção brasileira e sempre falavam: "Vão acontecer mudanças". Mas elas nunca saíram do papel, ficaram só nas promessas. Assim, até entendo que fica difícil para as meninas que estão nessa nova geração acreditarem, porque elas também estão vivenciando isso e as promessas são quase as mesmas de uns anos atrás de quando a gente estava. Mas é o que eu falo: "Quem está no poder é que tem que fazer alguma coisa". Mas enquanto elas tiverem uma luz lá no fim do túnel, alguma coisa que mesmo de longe a gente ainda continua aqui torcendo, mas sei lá fica 
difícil quando você vê que tem uma resistência das pessoas que estão acima, que tem o poder de fazer algo.

Silvana: Sissi, muito obrigada por conceder teu tempo para a entrevista.

Sissi: Eu é que tenho que agradecer. É bom relembrar do passado, relembrar o que a gente fez, o que a gente teve que passar e onde a gente chegou.$$
\text { *** }
$$

\section{Créditos das imagens}

Jogos Olímpicos de Atlanta, 1996, Getty Images, p. 117.

Copa do Mundo dos EUA, 1999, Getty Images, p. 122. Jogos Olímpicos de Atlanta, 1996, acervo da atleta, p. 126.

California Storm, 2012, Patti Giobetti, p. 128. Seatlle, 2015, acervo de Silvana Goellner, p. 133.

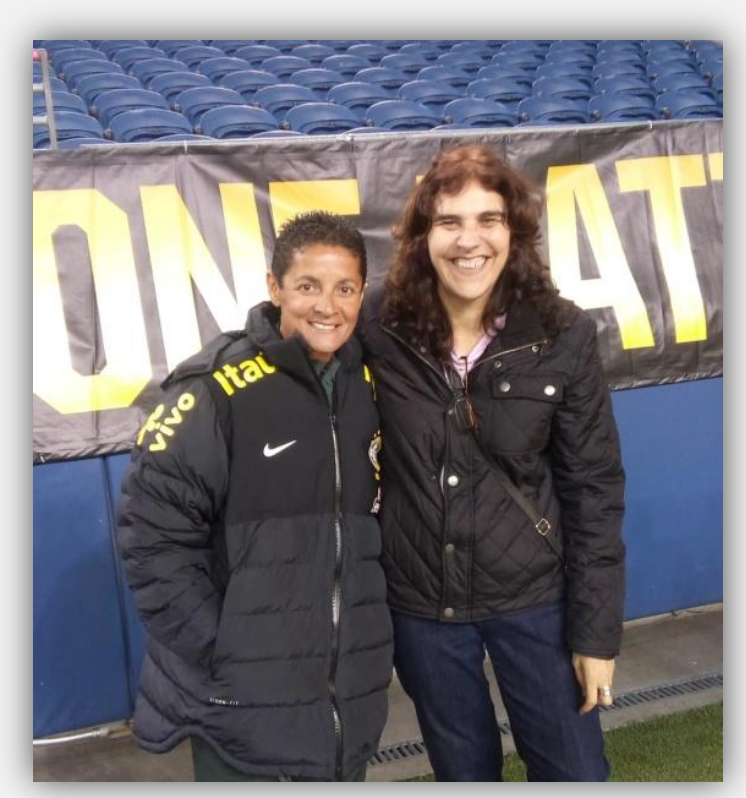

